Article

\title{
Evaluation of the Effect of Azospirillum brasilense and Mycor- rhizal Fungi of the Soil in Yacón Grown in a Greenhouse
}

\author{
Di Barbaro Gabriela' ${ }^{1}$, Andrada Horacio ${ }^{1}$, Del Valle Eleodoro ${ }^{2,3}$, Brandan de Weht Celia ${ }^{4}$ \\ ${ }^{1}$ Faculty of Agricultural Sciences, National University of Catamarca. Avda. Belgrano and Maestro Quiroga, \\ Argentina \\ 2 Faculty of Agrarian Sciences, National University of the Littoral, Argentina \\ ${ }^{3}$ National Council for Scientific and Technical Research, Argentina. \\ ${ }^{4}$ Faculty of Agronomy and Zootechnics, National University of Tucumán, Argentina \\ * Correspondence: gabydibarbaro@yahoo.com.ar
}

How to cite this paper: Barbaro Gabriela, D., Horacio, A., Eleodoro, D. V., \& Celia, B. de W. (2021). Evaluation of the Effect of Azospirillum Brasilense and Mycorrhizal Fungi of the Soil in Yacón Grown in a Greenhouse. Open Journal of Agricultural Research, 1(1), 8-15. DOI: 10.31586/ojar.2021.010102. Retrieved from https://www.scipublica-

tions.com/journal/index.php/ojar/article/view/4

Received: April 20, 2021

Accepted: June 15, 2021

Published: June 16, 2021

Copyright: (c) 2021 by the authors. Submitted for possible open access publication under the terms and conditions of the Creative Commons Attribution (CC BY) license (http://creativecommons.org/licenses /by/4.0/).

\begin{abstract}
In order to evaluate the effect of Azospirillum brasilense and mycorrhizal fungi in the soil on the nutrition of the yacon crop (Smallanthus sonchifolius [(Poeppig \& Endlicher) H. Robinson]), determinations of agronomic parameters and the health status of the plants were carried out, under greenhouse conditions. The tests were carried out at the time of the implantation of the culture: the propagules were inoculated with $A$. brasilense and with native mycorrhizal fungi, generating four treatments, including the control and the co-inoculation of the consortium of the microorganisms under study (T0: control or control without inoculation; T1: inoculation with native A. brasilense; T2: inoculation with native mycorrhizal fungi and T3: joint inoculation with $A$. brasilense and native mycorrhizal fungi. The results indicate that co-inoculation with $A$. brasilense and native mycorrhizal fungi increased plant growth in height, leaf area, biomass, dry matter and yields significantly in greenhouse production. It was determined that the application of the selected microorganisms has a plant growth promoting effect, increasing growth and productivity, greenhouse grown yacón.
\end{abstract}

Keywords: Interactions; co-inoculation; Smallanthus sonchifolius.

\section{Introduction}

The yacón (S. sonchifolius [(Poeppig \& Endlicher) H. Robinson]) of the botanical family Asteraceae is a tuber plant that originated in the Andes [1]. It was domesticated centuries ago by pre-Inca cultures whose original habitat is the highlands of the Andes, from southern Colombia to northern Argentina, in the provinces of Jujuy and Salta, between 800 and 2,800 meters above sea level, in temperate mountainous climates [2].

In contrast to other root crops, which store carbohydrates in the form of starch, yacón accumulates carbohydrates such as inulin and fructooligosaccharides (FOS). FOS are fructose polymers, which cannot be hydrolyzed by the human body and pass through the digestive tract without being metabolized, which is why it does not increase the level of glucose in the blood, providing lower calories than sucrose, excellent for low-calorie diets and diets for people with diabetes $[1,3,4,5]$. Its consumption is associated with other properties such as the reduction of cholesterol and triglycerides; improves calcium absorption, strengthens the immune system, prevents and reduces the risk of colon cancer, prevents constipation, and restores intestinal flora $[2,6,7,8]$. Therefore, as a nutraceutical food, yacón is associated with the prevention of chronic diseases (dyslipidemia and insulin resistance) and colon cancer, due to its antidiabetic, antioxidant and antimicrobial effects, among other properties $[9,10]$

It is an ideal food for people with diabetes and for people who want to lose weight since its consumption does not raise glucose concentration in the blood and provides very 
few calories to the diet. These properties are strongly associated with phenolic compounds and fructooligosaccharides (FOS), and it is proven that these compounds have beneficial effects on nutrition and health. The storage root of yacón has a pleasant sweet taste; it is usually consumed after a period of drying in the sun. This procedure increases the sweetness of the roots, and they are ready when the skin begins to wrinkle $[2,6]$.

The importance of yacón (S. sonchifolius) lies in bioactive components present mainly in the tuber and leaves of the plant, which has aroused great interest due to its content of FOS and phenolic compounds with beneficial properties for health. It contains FOS (50$70 \%$ of its dry weight). Therefore, prebiotic and recent studies have suggested that feeding yacón prevents and controls diabetes by lowering blood glucose [11]. In addition, the consumption of S. sonchifolius tubers is increasingly popular in the Japanese diet due to its low caloric value and high fibre content.

In Perú, yacón is a traditional crop, it is part of the food, and medicinal biodiversity and both the roots and the leaves are used there for their antioxidant, hypoglycemic and antibacterial properties. Due to these characteristics, its use as a functional and nutraceutical food is popular and promising [12]. It is marketed fresh and or in juices, syrups, capsules and tea in boxes with filter envelopes.

For all those above, it is considered valuable to increase the production of yacón by incorporating more productive and profitable cultivation technologies such as biofertilizers, which in turn allows to reduce production costs and reduce the use of agrochemicals.

Biofertilizers can contain one or more selected microorganisms, which can be applied to the seed or to the soil to increase its density and its association with the plant's root system to promote its nutrition. This improves the vegetative and productive development of the plant. Among the most widely used microorganisms for their potential contribution to plant, development is the rhizobacteria A. brasilense and the arbuscular mycorrhizal fungus Glomus intraradices [13].

Therefore, the objective of this work was to evaluate the effect of $A$. brasilense and mycorrhizal fungi native to the soil on the nutrition of the yacón crop ( $S$. sonchifolius [(Poeppig \& Endlicher) H. Robinson]), by determining parameters agronomic and plant health status.

\section{Materials and Methods}

The treatments carried out on yacón were:

- T0: Control or control (not inoculated).

- $\quad$ T1: Inoculation with A. brasilense.

- T2: Inoculation with native mycorrhizal fungi.

- $\quad$ T3: Joint inoculation with $A$. brasilense and native mycorrhizal fungi.

The inoculated treatments consisted of applying the selected microorganisms to the yacón propagules by immersing them in the inoculant just before implantation. At the same time, the propagules of the control treatments were placed in sterile tap water. Yacón (S. sonchifolius) propagules of about 30 grams were used.

The native strain Pi 8 of $A$. brasilense was used, isolated from the endorhizosphere of paprika (Capsicum annum var. Elephant trunk) cultivated in the Province of Catamarca, whose identification was carried out biochemically and molecularly $[14,15,16]$. The concentration of $A$. brasilense used for the inoculations was $5 \times 10^{7}$ azosp. $\mathrm{mL}^{-1}$ quantified in a Neubauer chamber [17].

The inoculum of mycorrhizal fungi native to the province was constituted by roots of Melilotus officinalis L., Avena sativa L., Hordeum vulgare L., Secale cereale L., Panicum maximun Jacq. and Cenchrus ciliaris L. colonized by these. The percentage of mycorrhizal colonization of the roots used as inoculum was $81.38 \%$, estimated by the method of online intersections and microscopic observation of roots of [18,19].

Two greenhouse experiments were carried out with unsterilized soil. 5-litre containers and soil from the agricultural area of the Central Valley of the Province of Catamarca 
were used (sand: 73.85 ; clay: $8 \%$; silt: $18.2 \%$; $\mathrm{pH}: 7.5 ; \mathrm{OM}: 5,72 \%$ ). A drip irrigation system was installed to irrigate the yacón crop.

Containers were filled with the same volume of sieved soil, watered with the same amount of water, and after the implementation of the different treatments, it was labelled. A layer of sterile perlite was added to avoid contamination and transfer of microbial inoculums between the plant's pots. The containers were later moved to the greenhouse.

The experimental design was completely randomized with 15 repetitions per treatment. At the end of the crop cycle, they recorded the following data: height of plants; the number of stems; leaf area index (IAF) [20], fresh weight (PF), dry (PS) and percentage of dry matter (\% DM) of stems, leaves, roots, propagules, tubers and whole plant; the number of tubers per plant; average weight and yield of tubers. With the data of dry weight (PS) and fresh weight (FP) the\% of dry matter (\% DM = PS x $100 /$ FP) was calculated, both for stems, tubers, roots and other parts of the plant.

The results were statistically analyzed using analysis of variance (ANOVA), and the means were compared using Fisher's LSD (Least Significant Difference) test at a significance level of 0.05 using the statistical program Infostat [21].

\section{Results}

Two experiments were carried out, collected and evaluated seven months after implantation.

Plant height: statistically significant differences were detected between the treatments in the two experiments. The plants inoculated with $A$. brasilense and mycorrhizal fungi (T3) presented higher height during the entire crop cycle (96 cm average) (Table 1).

Number of stems: In the inoculated treatments (T1, T2 and T3), the highest number of aerial stems were observed ( 3 stems), only registering significant differences concerning the control treatment (T0) (Table 1).

Percentage of dry matter of aerial stems: Significant statistical differences were obtained between the treatments. The highest percentages of dry matter of stems were observed with greater frequency in the treatments with inoculation of mycorrhizal fungi only (T2) $(62,79 \%$ and $60,26 \%)$ (Table 1$)$. The highest values of fresh weight (FP) and dry weight (PS) of stems were observed in the inoculated plants (T1, T2 and T3); however, statistically significant differences were recorded concerning the control plants, in the inoculated plants with mycorrhizal fungi (T2) $(66,2 \mathrm{~g}$ and $68,47 \mathrm{~g}$ of fresh weight; $40,91 \mathrm{~g}$ and 40,68 of dry weight) (Table 1).

Table 1. Comparison of agronomic parameters of yacón (number, fresh weight, dry weight, dry matter and height of stems) produced in a greenhouse with unsterilized soil.

\begin{tabular}{|c|c|c|c|c|c|}
\hline & \multirow{2}{*}{ Variable } & \multicolumn{4}{|c|}{ Treatments } \\
\hline & & Control & Azospirillum & Mycorrhizae & Azosp.+Myco. \\
\hline \multirow{5}{*}{ 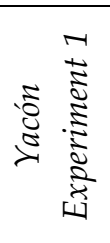 } & Nro. & $1,50 \pm 0,53$ a & $1,80 \pm 0,63$ a & $2,00 \pm 0,82$ a & $2,10 \pm 0,74$ a \\
\hline & $P F(g)$ & $58,34 \pm 5,33$ a & $75,16 \pm 5,17 \mathrm{c}$ & $66,20 \pm 6,83$ b & $95,46 \pm 7,46 \mathrm{~d}$ \\
\hline & $P S(g)$ & $28,04 \pm 5,31$ a & $43,11 \pm 7,87 \mathrm{~b}$ & $40,91 \pm 8,51^{b}$ & $44,37 \pm 12,18$ b \\
\hline & MS (\%) & $48,35 \pm 9,38$ а & $57,80 \pm 12,66 \mathrm{ab}$ & $62,79 \pm 16,62 \mathrm{~b}$ & $46,98 \pm 14,61$ a \\
\hline & Altura $(\mathrm{cm})$ & $62,40 \pm 3,66$ a & $77,90 \pm 5,61^{\text {с }}$ & $71,00 \pm 4,19^{\mathrm{b}}$ & $96,00 \pm 6,68 \mathrm{~d}$ \\
\hline \multirow{5}{*}{ 壳 } & Nro. & $1,33 \pm 0,52$ a & $1,50 \pm 0,55$ a & $1,83 \pm 0,75 \mathrm{ab}$ & $2,33 \pm 0,82$ b \\
\hline & $P F(g)$ & $58,22 \pm 6,73$ a & $77,92 \pm 4,12$ c & $68,47 \pm 7,31$ b & $98,93 \pm 6,84 \mathrm{~d}$ \\
\hline & $P S(g)$ & $26,88 \pm 5,90$ a & $41,08 \pm 3,99 \mathrm{~b}$ & $40,68+9,64$ b & $42,27 \pm 8,37$ b \\
\hline & $M S(\%)$ & $46,39 \pm 9,30$ а & $52,83 \pm 5,39$ a & $60,26 \pm 17,60 \mathrm{~b}$ & $43,10 \pm 10,36$ a \\
\hline & Altura $(\mathrm{cm})$ & $60,00 \pm 2,37$ a & $80,67 \pm 4,55$ c & $71,83 \pm 0,52$ b & $98,33 \pm 6,56 \mathrm{~d}$ \\
\hline
\end{tabular}

Uncommon letters in the same variable denote significant differences according to the LSD test (Minimum significant difference) for $P<0.05$. 
Number of tubers per plant: The number of tubers per plant is higher in the inoculated treatments; however, no significant statistical differences were recorded between the treatments (Table 2). It was observed that the maximum number of tubers per plant grown in pots are well below those obtained in field experiments. Due to the limitations of the volume of soil in the pots, the plants have less availability of nutrients and would not reach the size as if they were grown in the field.

Weight of tubers per plant: The highest weights of tubers per yacón plant were obtained in the treatments with the inoculation of the A. brasilense consortium and mycorrhizal fungi (T3) (126,58 g and 141,82 g average), where statistically significant differences were observed between the microbial co-inoculation treatments (T3) and control treatments (T0) (Table 2).

Percentage of dry matter of the tubers: A higher percentage of dry matter was determined in the tubers of the inoculated treatments, mainly with the co-inoculation of the microbial consortium (T3) (22,9\% average), observing statistically significant differences concerning the controls (T0) (Table 2).

Average weight of the tubers: The larger tubers, with the highest average weight, were observed in the inoculated treatments (80,36 $\mathrm{g}$ and $91,83 \mathrm{~g}$ average), registering significant statistical differences concerning the control treatment (T0) (Table 2).

Yield ( $t$ of tubers per ha-1): The highest yields were achieved with the inoculation of the microbial consortium made up of A. brasilense and mycorrhizal fungi (T3) (Table 2). However, yields much lower than those obtained in field trials were achieved.

Table 2. Comparison of agronomic parameters of yacón (number, fresh weight, dry weight, dry matter, average weight and tuber yield) produced in greenhouse with unsterilized soil.

\begin{tabular}{|c|c|c|c|c|c|}
\hline & \multirow{2}{*}{ Variable } & \multicolumn{4}{|c|}{ Treatments } \\
\hline & & Control & Azospirillum & Mycorhizae & Azosp.+Myco. \\
\hline \multirow{6}{*}{ 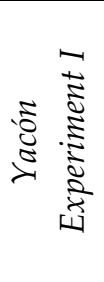 } & Nro. & $1,40 \pm 0,52$ a & $1,50 \pm 0,53$ a & $1,80 \pm 0,63$ a & $1,70 \pm 0,48^{\text {a }}$ \\
\hline & $P F(g)$ & $32,01 \pm 8,83$ a & $73,17 \pm 25,17$ b & $96,66 \pm 20,01^{b}$ & $126,58 \pm 52,83 \mathrm{c}$ \\
\hline & $P S(g)$ & $6,66 \pm 1,84$ a & $16,32 \pm 5,61 \mathrm{~b}$ & $21,46 \pm 4,44 \mathrm{~b}$ & $29,09 \pm 12,14^{\mathrm{c}}$ \\
\hline & $M S(\%)$ & $20,80 \pm 0,01$ a & $22,30 \pm 0,01^{c}$ & $22,20 \pm 0,043$ b & $22,98 \pm 0,029 \mathrm{~d}$ \\
\hline & $P M(g)$ & $25,50 \pm 9,75$ а & $52,09 \pm 17,13 \mathrm{~b}$ & $63,22 \pm 34,21^{\mathrm{bc}}$ & $80,36 \pm 39,45^{c}$ \\
\hline & Rdto. $($ t.ha-1) & $0,653 \pm 0,18$ a & $1,493 \pm 0,513 \mathrm{~b}$ & $1,973 \pm 0,408^{\mathrm{b}}$ & $2,583 \pm 1,078 \mathrm{c}$ \\
\hline \multirow{6}{*}{ 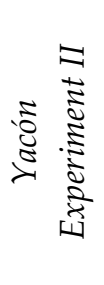 } & Nro. & $1,50 \pm 0,55$ a & $1,67 \pm 0,52$ a & $1,67 \pm 0,52$ a & $1,67 \pm 0,52$ a \\
\hline & $P F(g)$ & $32,48 \pm 11,34^{\mathrm{a}}$ & $83,47 \pm 26,98^{b}$ & $101,77 \pm 25,22 \mathrm{bc}$ & $141,82 \pm 64,58^{\mathrm{c}}$ \\
\hline & $P S(g)$ & $6,76 \pm 2,366^{a}$ & $18,62 \pm 6,02 \mathrm{~b}$ & $22,60 \pm 5,60 \mathrm{bc}$ & $32,58 \pm 14,84^{\mathrm{c}}$ \\
\hline & $M S(\%)$ & $20,79 \pm 0,01^{\mathrm{a}}$ & $22,31 \pm 0,029$ c & $22,20 \pm 0,033$ b & $22,97 \pm 0,04 \mathrm{~d}$ \\
\hline & $P M(g)$ & $24,25 \pm 10,94^{\mathrm{a}}$ & $53,36 \pm 18,01 \mathrm{ab}$ & $70,76 \pm 39,18^{\mathrm{b}}$ & $91,83 \pm 46,72 \mathrm{~b}$ \\
\hline & Rdto.(t.ha-1) & $0,663 \pm 0,232^{a}$ & $1,704 \pm 0,551$ b & $2,077 \pm 0,515 \mathrm{bc}$ & $2,895 \pm 1,318 \mathrm{c}$ \\
\hline
\end{tabular}

Uncommon letters in the same variable denote significant differences according to the LSD test (Minimum significant difference) for $P<0.05$.

Leaf Area Index (IAF): In yacón plants from the inoculated treatments, the highest IAFs were determined (4706,50 $\mathrm{cm}^{2}$ and $4845 \mathrm{~cm}^{2}$ average), establishing statistically significant differences in favor of the inoculated treatments compared to the controls (Table 3).

Fresh weight of leaves per plant: The highest production of foliar mass was observed in the yacón plants from the inoculated treatments (94,13 $\mathrm{g}$ and 96,8 $\mathrm{g}$ average), establishing statistically significant differences in favor of the inoculated treatments compared to the controls (Table 3).

Leaf dry matter percentage: The highest foliar dry matter values were observed in the co-inoculation treatment with the microbial consortium (T3) (19\% average) (Table 3). 
Root dry matter percentage: The highest root biomasses were obtained in the inoculated plants, registering significant statistical differences between the treatments in both experiments. In addition, the highest values of dry matter of propagules and roots were observed in the inoculation treatment with the microbial consortium (T3) (23,4 \% average) (Table 3). Results that show the root growth promoting activity of the microorganisms under study.

Table 3. Comparison of agronomic parameters of yacón (leaf area index, fresh weight, dry weight and dry matter of leaves, propagules and roots) produced in Greenhouse with unsterilized soil.

\begin{tabular}{|c|c|c|c|c|c|}
\hline & \multirow{2}{*}{ Variable } & \multicolumn{4}{|c|}{ Treatments } \\
\hline & & Control & Azospirillum & Mycorhizae & Azosp.+Мyco. \\
\hline \multirow{7}{*}{ 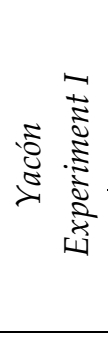 } & $\operatorname{IAF}\left(\mathrm{cm}^{2}\right)$ & $2777,00 \pm 293,02$ a & $3463,50 \pm 284,04$ b & $3299,00 \pm 291,89^{b}$ & $4706,50 \pm 362,94^{\mathrm{c}}$ \\
\hline & PFhoja $(g)$ & $55,54 \pm 5,86^{a}$ & $69,27 \pm 5,68^{b}$ & $65,98 \pm 5,84^{b}$ & $94,13 \pm 7,26^{c}$ \\
\hline & $P S_{\text {hoja }}(g)$ & $9,61 \pm 1,01$ a & $12,88 \pm 1,06^{b}$ & $12,21 \pm 1,08^{b}$ & $17,88 \pm 1,38^{c}$ \\
\hline & $M S_{\text {hoja }}(\%)$ & $17,30 \pm 0,0047$ a & $18,60 \pm 0,044^{\mathrm{c}}$ & $18,50 \pm 0,0034^{\mathrm{b}}$ & $18,99 \pm 0,018^{\mathrm{d}}$ \\
\hline & $P F_{r z+p r}(g)$ & $154,08 \pm 29,19$ a & $220,98 \pm 39,99 \mathrm{~b}$ & $206,63 \pm 43,01 \mathrm{~b}$ & $219,62 \pm 60,28 \mathrm{~b}$ \\
\hline & $P S_{r z+p r}(g)$ & $29,58 \pm 5,61$ a & $47,94 \pm 8,68$ b & $44,74 \pm 9,31$ b & $51,39 \pm 14,11$ b \\
\hline & $M S_{r z+p r}(\%)$ & $19,20 \pm 0,017$ a & $21,69 \pm 0,02$ c & $21,65 \pm 0,019^{b}$ & $23,40 \pm 0,013 \mathrm{~d}$ \\
\hline \multirow{7}{*}{ 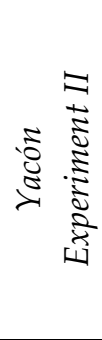 } & $\operatorname{IAF}\left(\mathrm{cm}^{2}\right)$ & $2783,33 \pm 381,85$ a & $3585,0 \pm 172,08$ b & $3369,17 \pm 344,77$ b & $4845,0 \pm 325,67 \mathrm{c}$ \\
\hline & PF hoja $(g)$ & $55,67 \pm 7,64{ }^{a}$ & $71,7 \pm 3,44$ b & $67,38 \pm 6,90^{b}$ & $96,90 \pm 6,31^{c}$ \\
\hline & $P S_{\text {hoja }}(g)$ & $9,63 \pm 1,32$ a & $13,34 \pm 0,64$ b & $12,47 \pm 1,27$ b & $8,42 \pm 1,2$ c \\
\hline & $M S_{\text {hoja }}(\%)$ & $17,30 \pm 0,01^{\text {a }}$ & $18,60 \pm 0,044^{\mathrm{c}}$ & $18,51 \pm 0,047$ b & $19,00 \pm 0,03 \mathrm{~d}$ \\
\hline & $P F_{r z+p r}(g)$ & $147,67 \pm 32,43$ a & $209,60 \pm 20,33$ b & $205,47 \pm 48,68$ b & $209,25 \pm 41,44^{b}$ \\
\hline & $P S_{r z+p r}(g)$ & $28,36 \pm 6,23$ a & $54,49 \pm 4,41^{\mathrm{b}}$ & $44,49 \pm 10,54$ b & $48,97 \pm 9,69$ b \\
\hline & $M S_{r z+p r}(\%)$ & $19,20 \pm 0,019$ a & $21,70 \pm 0,001^{\mathrm{c}}$ & $21,65 \pm 0,013^{\mathrm{b}}$ & $23,40 \pm 0,028 \mathrm{~d}$ \\
\hline
\end{tabular}

The evaluation of the complete plant showed a higher growth of the inoculated plants, observing statistically significant differences concerning the control plants in the variable's percentage of dry matter, fresh and dry biomass (27 \% of dry matter; 527,32 $\mathrm{g}$ and 546,9 $\mathrm{g}$ of fresh biomass; $142 \mathrm{~g}$ of dry biomass average) (Table 3).

In summary, with the application of the microbial consortium to the cultivation of yacón, better vegetative behavior and higher production of tubers were obtained under greenhouse cultivation conditions.

Table 4. Comparison of agronomic parameters of yacón (fresh weight, dry weight and dry mass of whole plants) produced in a greenhouse with unsterilized soil.

\begin{tabular}{|c|c|c|c|c|c|}
\hline & \multirow{2}{*}{ Variable } & \multicolumn{4}{|c|}{ Treatments } \\
\hline & & Control & Azospirillum & Mycorhizae & Azosp.+Myco. \\
\hline \multirow{3}{*}{ 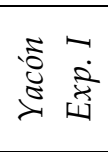 } & $P F(g)$ & $299,97 \pm 39,36$ a & $430,16 \pm 56,06^{b}$ & $424,15 \pm 49,76$ b & $527,32 \pm 88,95^{c}$ \\
\hline & $P S(g)$ & $73,89 \pm 12,44^{a}$ & $120,05 \pm 17,11^{b}$ & $119,31 \pm 17,43$ b & $142,72 \pm 27,51^{\mathrm{c}}$ \\
\hline & $M S(\%)$ & $24,55 \pm 1,20$ a & $27,95 \pm 2,27$ b & $28,15 \pm 2,91^{\mathrm{b}}$ & $27,08 \pm 2,73$ b \\
\hline \multirow{3}{*}{ 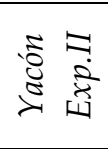 } & $P F(g)$ & $294,03 \pm 49,39$ a & $430,32 \pm 56,33^{b}$ & $443,08 \pm 55,60$ b & $546,90 \pm 81,97 \mathrm{c}$ \\
\hline & $P S(g)$ & $71,61 \pm 14,71^{a}$ & $118,51 \pm 11,55^{b}$ & $120,22 \pm 19,89$ b & $142,22 \pm 23,73 \mathrm{c}$ \\
\hline & MS (\%) & $24,27 \pm 1,15$ a & $27,73 \pm 2,66 \mathrm{~b}$ & $27,05 \pm 1,90 \mathrm{~b}$ & $25,98 \pm 1,69 \mathrm{ab}$ \\
\hline
\end{tabular}

Uncommon letters in the same variable denote significant differences according to the LSD test (Minimum significant difference) for $P<0.05$. 


\section{Discussion}

Although the results obtained are in many cases inferior to those achieved in other parts of the world, many reasons can explain the differences. In yacón, the plantation of propagules of 50 grams gave an average yield of the tuberous root of $2 \mathrm{~kg} /$ plant or $26.6 \mathrm{t} /$ ha, 200 grams gave $5 \mathrm{~kg} /$ plant or $66.5 \mathrm{t} /$ ha, and 500 grams produced $6 \mathrm{~kg} /$ plant or $79.8 \mathrm{t} /$ ha, showing that the weight of the propagules has a great effect on the yield of tuberous yacón root [7]. In this work, the yacón plantations were started with propagules of $30 \mathrm{~g}$ average; this is one of the main reasons for the low productivity values obtained. It is recommended that a 180-200 $\mathrm{g}$ piece of propagule be used to establish yacón cultures for tuberous root production. This sowing weight increased the crowns in weight ten times [7].

However, the results obtained showed an increase in the different variables of vegetable production evaluated (plant height, number of tubers and propagules, fresh weight and dry weight of stems, roots, propagules and tubers) in yacón plants. Due to the effect of the inoculation with native microorganisms of A. brasilense and mycorrhizal fungi, they are registering significant statistical differences concerning the control plants without inoculation. Therefore, the highest productivity of this culture is obtained by microbial inoculation of the propagules when implantation of the culture.

The microbial consortium used, made up of native, bacterial and fungal strains, generated the best results due to the greater intake of water and nutrients, and mainly nitrogen. This can be incorporated into the soil by biological nitrogen fixation since the bacterium $A$. brasilense has this capacity and synthesizes auxins and other phytohormones [22]. The greater uptake of water and nutrients, especially those not very mobile such as phosphorus, facilitate their availability and assimilation by plants [23-26]. In addition, these microorganisms locate and colonize sites in the rootlets, which could potentially be occupied by phytopathogens [27].

The selection of effective microorganisms in promoting the growth of cultures is a great challenge. The adaptation to the environment to which they are introduced and the compatibility between the microorganisms that make up the microbial consortia and these with the plants may be the factors that prevent their use in agricultural production.

This work contributes to making evident the potential of the selected microorganisms as an alternative to improve the nutrition and productivity of the yacón culture. These results could support the possible use of microbial inoculants in the production of this crop, which would avoid or reduce chemical fertilizers. They also indicate a direct effect of microbial inoculation on the growth and yields of the yacón culture. In addition, it is important to note that these microbial interactions with yacón roots were achieved with native microorganisms and that the cultures were carried out in lots with no previous production history of these crops. Similarly, to the fact that they are non-traditional crops in the province and produced almost exclusively by a single farmer in the Central Valley area of Catamarca.

\section{Conclusions}

The inoculations of "seed" propagules at the time of implantation of the yacón ( $S$. sonchifolius) culture with the selected microorganisms positively affected greenhouse culture conditions; they evaluated their development and productivity improvement due to better and increased nutrition.

Significant differences were detected in the variables evaluated due to the treatments applied to the yacón crop. The harvest of the crops in the phenological stage of "delivery" and tuber maturity, together with the variables associated with the production of tubers (quantity, fresh weight, dry weight, yield, etc.), are the most consistent.

The microbial consortium's application increased the potentiality of the culture, obtaining the best results due to the co-inoculation with the consortium of $A$. brasilense and 
mycorrhizal fungi (T3), achieving increases in yield of $300 \%$ average, widely exceeding the controls.

The application of microorganisms in studies in the implantation of yacón culture in greenhouse trials allowed the establishment of beneficial relationships, ensuring survival, promoting the growth of plants in their first stages of growth fundamentally and increasing the yield of crops.

The microbial inocula used in these experiments are native species, and due to their origin, they have generated more adequate adaptation mechanisms to the environmental conditions. It is estimated that this is one of the reasons for which promising results have been presented for the growth of the yacón crop.

This study is a pioneer in the studied area, so it is considered very promising to obtain a higher production and innovate with the cultivation of yacón, for its application with multiple purposes.

\section{References}

[1] Fernández E.C.; Viehmannová I.; Lachman J.; Milella L. (2006). Yacón [Smallanthus sonchifolius (Poeppig \& Endlicher) H. Robinson]: a new crop in the Central Europe. Plant Soil Environ. 52 (12): 564-570.

[2] Manrique I.; Parraga A.; Hermann M. (2005). Yacón syrup: Principles and processing (8B). Conservation and use of Andean root and tuber biodiversity: A decade of research for development (1993-2003). International Potato Center. Lima Peru: 31p.

[3] Wagner M.; Kamp L.; Graeff-Hönninger S.; Lewandowski I. (2019). Environmental and economic performance of yacon (Smallanthus sonchifolius) cultivated for fructooligosaccharide production. Sustain. (https://doi.org/10.3390/su 11174581).

[4] Singh R.S.; Singh T.; Larroche C. (2019). Biotechnological applications of inulin-rich feedstocks. Bioresource Technol. (https://doi.org/10.1016/j. biortech.2018.11.031).

[5] Silveira Adriano L.; Dionísio A.P.; Pinto de Abreu F.A.; Ferreira Carioca A.A.; Zocolo G.J.; Wurlitzer N.J.; de Oliveira Pinto C.; Cunha de Oliveira A.; de Carvalho Sampaio H.A. (2019). Yacon syrup reduces postprandial glycemic response to breakfast: A randomized, crossover, double-blind clinical trial. Food Res. Intern. (https://doi.org/10.1016/j.foodres.2019.108682).

[6] Santana I.; Cardoso M.H. (2008). Tuberous root of yacon (Smallanthus sonchifolius): cultivation potential, technological and nutritional aspects. Rural Science. Sta. Ma. 38 (3): 898-905.

[7] Muñoz Jáuregui A.M. (2010). Monograph of the yacón Smallanthus sonchifolius (Poepp. \& Endl.). Perubiodiverse. Lima Peru. (http://perubiodiverso.pe/assets/Monograf\% C3\% ADa-del-yac\% C3\% B3n.pdf).

[8] Yan M.R.; Welch R.; Rush E.C.; Xiang X.; Wang X. (2019). A Sustainable Wholesome Foodstu; Health Effects and Potential Dietotherapy Applications of Yacon. Nutrients. (https://doi.org/10.3390/nu11112632).

[9] Geyer M.; Manrique I.; Degen L.; Beglinger C. (2008). Effect of yacón (Smallanthus sonchifolius) on colonic transit time in healthy volunteers. Digestion. 78 (1): 30-33.

[10] Genta S.; Cabrera C.; Habib N.; Pons J.; Manrique I.; Grau A.; Sánchez S. (2009). Yacón syrup: Beneficial effects on obesity and insulin resistance in humans. Clinical Nutrit. 28 (2): 182-187.

[11] Satoh H.; Audrey Nguyen M.T.; Kudoh A.; Watanabe T. (2013). Yacón diet (Smallanthus sonchifolius, Asteraceae) improves hepatic insulin resistance via reducing Trb3 expression in Zucker fa / fa rats. Nutrit. \& Diabetes. 3: 1-6.

[12] Arnao I.; Seminario J.; Cisneros R.; Trabucco J. (2011). Antioxidant potential of 10 accessions of yacon, Smallanthus sonchifolius (Poepp. \& Endl.) H. Robinson, from Cajamarca - Peru. Annals of the Fac. Of Medicine. (http://dx.doi.org/10.15381/anales.v72i4.1075).

[13] Mrosk C.; Forner S.; Hause G.; Küster H.; Kopka J.; Hause B. (2009). Composite Medicago truncatula plants harboring Agrobacterium rhizogenes-transformed roots reveal normal mycorrhization by Glomus intraradices. J. Exp. Bot. 60 (13): 3797-3807.

[14] Tarrand J.J.; Krieg N.R.; Döbereiner J. (1978). A taxonomic study of the Spirillum lipoferum group, with descriptions of a new genus, Azospirillum gen. Nov. and two species, Azospirillum lipoferum (Beijerinck) comb. Nov. and Azospirillum brasilense sp. Nov. Dog. J. Microbiol. 24 (8): 967-980.

[15] Döbereiner J.; Baldani V.L.D.; Baldani J.I. (1995). How to isolate and identify diazotrophic bacteria from legume plants. Brasília: EMBRAPA-SPI. Itaguaí, RJ: EMBRAPA-CNPAB. : 11-60.

[16] Caballero-Mellado J. (2002). El género Azospirillum. :177-198. In “Microbios en línea". (E. Martinez-Romero y J. MartínezRomero). Univ. Nac. Autónoma de México. (http://biblioweb.dgsca.unam.mx/libros/microbios).

[17] Manacorda A.M.; Tables D.P.; Álvarez A.S. (2007). Practical Manual of Microbiology - Volume I: Environmental Microbiology I. Cap. 8: Microorganism count. 8p.

[18] Sieverding E. (1983). Mycorrhiza Project. International Center for Tropical Agriculture. Cali. Colombia. 121p.

[19] McGonigle T.P.; Miller M.H.; Evans D.G.; Fairchild G.L.; Swan J.A. (1990). A new method which gives an objective measure of colonization of roots by vesicular-arbuscular mycorrhizal fungi. New Phytol. 115: 495-501.

[20] Lal K.; Subba Rao M.A. (1951). Rapid Method of Leaf Area Determination. Nature. (https://doi.org/10.1038/167072a0). 
[21] Di Rienzo J.A.; Casanoves F.; Balzarini M.G.; Gonzalez L.; Tablada M.; Robledo C.W. (2018). InfoStat versión 2018. Centro de Transferencia InfoStat, FCA, Univ. Nac. de Córdoba, Argentina. URL (http://www.infostat.com.ar).

[22] Larraburu E.E.; Yarte M.E.; Llorente B.E. (2016). Azospirillum brasilense inoculation, auxin induction and culture medium composition modify the profile of antioxidant enzymes during in vitro rhizogenesis of pink lapacho. Plant Cell Tiss Organ Cult (https://doi.org/10.1007/s11240-016-1060-z).

[23] Kirk P.M.; Cannon P.F.; David J.C.; Stalpers J. (2001). Ainsworth and Bisby's Dictionary of the Fungi. 9th ed. CAB International, Wallingford, UK. (https://doi.org/10.1016 /S0024-2829 (03) 00055-0).

[24] Selosse M. A.; Richard F.; He X.; Simard S.W. (2006). Mycorrhizal networks: des liaisons dangereuses? Trends Ecol. Evil. (https://doi.org/10.1016/j.tree.2006.07. 003).

[25] Harrison M.J. (2005). Signaling in the arbuscular mycorrhizal symbiosis. Annu. Rev. Microbiol. (https://doi.org/10.1146/annurev.micro.58.030603.123749).

[26] Wang B.; Qiu Y.L. (2006). Phylogenetic distribution and evolution of mycorrhizas in land plants. Mycorrhizahello (https://link.springer.com/article/10.1007/s00572-005-0033-6).

[27] Newsham K.K.; Fitter A.H.; Watkinson A.R. (1995). Multi-functionality and biodiversity in arbuscular rmycorrhizas. Trends in Ecol. Evol. 10: 407-411. 